University of Nebraska - Lincoln

DigitalCommons@University of Nebraska - Lincoln

Faculty Papers and Publications in Animal

Science

Animal Science Department

October 1984

\title{
EFFECT OF CASTRATION ON PLASMA LUTEINIZING HORMONE CONCENTRATIONS IN PREPUBERTAL BOARS
}

\author{
R. J. Kittock \\ University of Nebraska-Lincoln \\ J. E. Kinder \\ University of Nebraska-Lincoln, kinder.15@osu.edu \\ R. K. Johnson \\ University of Nebraska-Lincoln, rjohnson5@unl.edu
}

Follow this and additional works at: https://digitalcommons.unl.edu/animalscifacpub

Part of the Animal Sciences Commons

Kittock, R. J.; Kinder, J. E.; and Johnson, R. K., "EFFECT OF CASTRATION ON PLASMA LUTEINIZING HORMONE CONCENTRATIONS IN PREPUBERTAL BOARS" (1984). Faculty Papers and Publications in Animal Science. 35.

https://digitalcommons.unl.edu/animalscifacpub/35

This Article is brought to you for free and open access by the Animal Science Department at DigitalCommons@University of Nebraska - Lincoln. It has been accepted for inclusion in Faculty Papers and Publications in Animal Science by an authorized administrator of DigitalCommons@University of Nebraska - Lincoln. 


\title{
EFFECT OF CASTRATION ON PLASMA LUTEINIZING HORMONE CONCENTRATIONS IN PREPUBERTAL BOARS ${ }^{1}$
}

\author{
R. J. Kittok, J. E. Kinder and R. K. Johnson \\ University of Nebraska ${ }^{2}$, \\ Lincoln 68583-0908
}

\section{Summary}

Mean concentrations and the occurrence of pulsatile release of luteinizing hormone (LH) were determined in 14-wk-old crossbred boars $(50.5 \pm 1.5 \mathrm{~kg})$ after bilateral or unilateral castration at $10 \mathrm{wk}$ of age. Blood was collected at 10 -min intervals for $5 \mathrm{~h}$. Then gonadotropin releasing hormone $(\mathrm{GnRH} ; 40 \mu \mathrm{g})$ was given and sampling was continued at 5 -min intervals for $1 \mathrm{~h}$. Compared with intact boars, bilateral castration increased $(\mathrm{P}<.001)$ mean LH $(982 \pm$ 56 vs $389 \pm 56 \mathrm{pg} / \mathrm{ml})$, pulsatile releases of $\mathrm{LH}$ $(7.0 \pm .6$ vs $2.0 \pm .6$ pulses $/ 5 \mathrm{~h})$ and $\mathrm{LH}$ pulse amplitude $(617 \pm 29$ vs $360 \pm 58 \mathrm{pg} / \mathrm{ml})$. Unilaterally castrated boars did not differ from intact boars in any of the above measures of $\mathrm{LH}$ secretion. Testis weight increased more between 10 and $14 \mathrm{wk}$ of age in the unilateral castrates than in the intact boars $(432 \pm 42$ vs $245 \pm$ $34 \% ; \mathrm{P}<.05)$. Thus, compensatory hypertrophy occurred within 4 wk of castration. Plasma testosterone was lower for bilateral castrates than for intact animals $(.1 \pm .8$ vs $3.6 \pm .9$ $\mathrm{ng} / \mathrm{ml} ; \mathrm{P}<.05)$ while unilateral castrates $(3.8 \pm$ $1.0 \mathrm{ng} / \mathrm{ml}$ ) and intact boars did not differ. Plasma estradiol concentrations in bilateral and

\footnotetext{
${ }^{1}$ Published as Paper No. 7202 Journal Series, Nebraska Agr. Exp. Sta. The authors acknowledge and appreciate receiving the following reagents: synthetic gonadotropin releasing hormone from Dr. $R$. $H$. Rippel, Abbot Laboratories, N. Chicago, IL; porcine LH antiserum (No. 566) from Dr. G. D. Niswender, Dept. of Physiol. and Biophys., Colorado State Univ., Fort Collins; purified porcine LH (LER-786-3) from Dr. L. E. Reichert, Jr., Dept. of Biochem., Albany Medical College, Albany, NY; estradiol-17 $\beta$ antiserum (Lilly No. 022673) from Dr. N. R. Mason, Eli Lilly Co., Indianapolis, IN, and testosterone antiserum (MSU No. 74) from Dr. E. M. Convey, Anim. Sci. Dept., Michigan State Univ., East Lansing.

${ }^{2}$ Anim. Sci. Dept.

Received June 17, 1983.

Accepted November 4, 1983.
}

unilateral castrates were not different from levels found in intact boars $(1.8 \pm 1.8,8.8 \pm 2.1$ and $6.0 \pm 1.8 \mathrm{pg} / \mathrm{ml}$, respectively). While mean LH after GnRH was higher in bilateral and unilateral castrates than in intact boars $(2,588 \pm$ 147 and $2,693 \pm 164$ vs $1,928 \pm 147 \mathrm{pg} / \mathrm{ml}$; $\mathrm{P}<.01$ ), castration did not affect the highest $\mathrm{LH}$ level after $\mathrm{GnRH}$, time of highest level, magnitude of LH change or rate of $\mathrm{LH}$ response during the first $15 \mathrm{~min}$ after $\mathrm{GnRH}$. The rate of change of LH from 0 min to time of maximum $\mathrm{LH}$ of the bilateral castrates tended to be greater than that in intact boars $(b=202$ vs 94 ; $\mathrm{P}<.10$ ). These data indicate that the negative feedback of gonadal steroids affects LH secretion.

(Key Words: Boars, Puberty, Luteinizing Hormone, Gonadotropin Releasing Hormone, Castration.)

\section{Introduction}

Control of luteinizing hormone (LH) secretion in the boar is assumed to involve negative feedback of gonadal steroids similar to that demonstrated in rams (Riggs and Malven, 1974; D'Occhio et al., 1982b) and bulls (Schanbacher, 1981; Schanbacher et al., 1983). Compared with intact boars, blood LH concentrations were elevated in castrated prepubertal (Colenbrander et al., 1977) and adult (FlorCruz and Lapwood, 1978) boars within 2 to 4 wk postcastration. However, Allrich et al. (1982) did not observe elevated serum LH at d 4,8 or 16 postcastration in boars castrated at $70 \mathrm{~d}$ of age or older. The effect of castration of boars on pulsatile release of $\mathrm{LH}$ and amplitude of $\mathrm{LH}$ pulses has not been reported. Thus, the role of gonadal steroids in the control of $\mathrm{LH}$ secretion in the boar is unclear.

The objective of the present study was to determine the role of testicular steroids in 1271 
boars. Bilateral and unilateral castration were used to alter testicular steroids. Testicular steroids were to be reduced to minimum concentrations by bilateral castration. It was anticipated that unilateral castration would provide a treatment group in which testicular steroid concentrations were intermediate to that of intact and bilaterally castrated boars. As part of this study, the ability of the pituitary gland to release $\mathrm{LH}$ after castration was assessed with a challenge of gonadotropin releasing hormone (GnRH).

\section{Materials and Methods}

Three crossbred boars from each of five litters were used. The boars were from a composite population that was at least $50 \%$ Large White $x$ Landrace breeds, with the remainder being comprised of a mixture of breeds. All boars in the present experiment were of similar genetic background. At $10 \mathrm{wk}$ of age, one boar from each litter was bilaterally castrated and a second boar from each litter was unilaterally castrated. Associated connective tissue, blood vessels and epididymides were trimmed from the testes before the gonads were weighed. The third boar from each litter remained intact.

At 14 wk of age, all boars $(50.5 \pm 1.5 \mathrm{~kg}$; mean $\pm \mathrm{SE}$ ) were fitted with an indwelling jugular catheter. Two days after the catheterization, blood samples were collected at $10-\mathrm{min}$ intervals for $5 \mathrm{~h}$. Then a challenge of GnRH (40 $\mu \mathrm{g})$ was administered via the catheter and the catheter was flushed with approximately $3 \mathrm{ml}$ of sterile sodium citrate $(3.5 \%)$. Thereafter, blood sampling continued for $1 \mathrm{~h}$ at 5 -min intervals. One boar in the unilateral castration group died before the catheterization. The dose of GnRH used in the present study was to have been a challenge approximately midway (on a log-dose basis) between the doses of .2 and 2.0 $\mu \mathrm{g} / \mathrm{kg}$ of body weight given to intact pubertal boars by Pomerantz et al. (1974).

Each blood sample $(4.8 \mathrm{ml})$ was mixed with $60 \mu \mathrm{l}$ of $15 \%$ ethylenediaminetetracetic acid (EDTA) in the form of a dipotassium salt. The samples were then stored on ice ( $6 \mathrm{~h}$ or less) until centrifugation and removal of plasma. Plasma was stored at $-20 \mathrm{C}$ until quantification of hormones. After collection of the blood samples, all remaining testes were removed, trimmed as described above and weighed.

Luteinizing hormone in each plasma sample was determined in duplicate $300-\mu$ l aliquots by a homologous radioimmunoassay as described by Niswender et al. (1970). Purified porcine LH (LER-786-3) was used as reference and iodinated preparations. Intra- and interassay coefficients of variation were 5.2 and $16.6 \%$, respectively. Assay sensitivity was $22.9 \mathrm{pg} /$ tube.

The number of pulsatile releases of $\mathrm{LH}$ during the $5 \mathrm{~h}$ before the GnRH challenge was estimated for each boar. A pulse was defined as a peak of LH that occurred within $20 \mathrm{~min}$ of the previous nadir and whose lower $66 \%$ confidence limit was higher than the upper $66 \%$ confidence limit of both the preceding and subsequent nadirs. The probability of determining an episode to be a pulse when in fact the individual samples have the same value is $<.05$. Maximum pulse amplitude was estimated by subtracting the concentration of the preceding nadir from the concentration of the peak of the pulse.

Aliquots from the first 12 samples from each pig were pooled and used for the determination of estradiol and testosterone. Plasma estradiol concentrations were determined by methods that were similar to those described by D'Occhio et al. (1982a). The specificity of the antiserum against estradiol was reported by Kesler et al. (1977). Procedural loss was assessed and assay determinations were corrected for that loss. Recovery of added mass $(10,25,50$ and $75 \mathrm{pg}$ estradiol) from $500 \mu \mathrm{l}$ of plasma from an ovariectomized gilt averaged $106 \pm 2 \%$. Assay determinations of $300,500,800,1,000$ and $1,400 \mu \mathrm{l}$ of sample volume were parallel to the standard curve and were $56.5,57.3,55.2,53.3$ and $52.0 \mathrm{pg} / \mathrm{ml}$, respectively. Intraassay coefficient of variation was $1.6 \%$. All estradiol determinations were completed within a single assay with assay sensitivity of $.59 \mathrm{pg} /$ assay tube.

Plasma testosterone concentrations were determined by methods similar to those described by Kiser et al. (1978). The specificity of the antiserum against testosterone was reported by Kiser et al. (1978). Recovery of added mass $(62.5,125$ and $250 \mathrm{pg}$ testosterone) from $100 \mu \mathrm{l}$ of serum averaged $85 \pm 3 \%$. Assay determinations of 25 and $50 \mu \mathrm{l}$ of sample from each of four independent samples were highly correlated $(r=.99)$. Testosterone determinations were completed in a single assay with an intraassay coefficient of variation of $1.8 \%$ and a sensitivity of 5.7 $\mathrm{pg} / \mathrm{ass} a y$ tube.

The LH determinations from samples before and after the GnRH challenge were statistically analyzed separately as split-plot designs for 


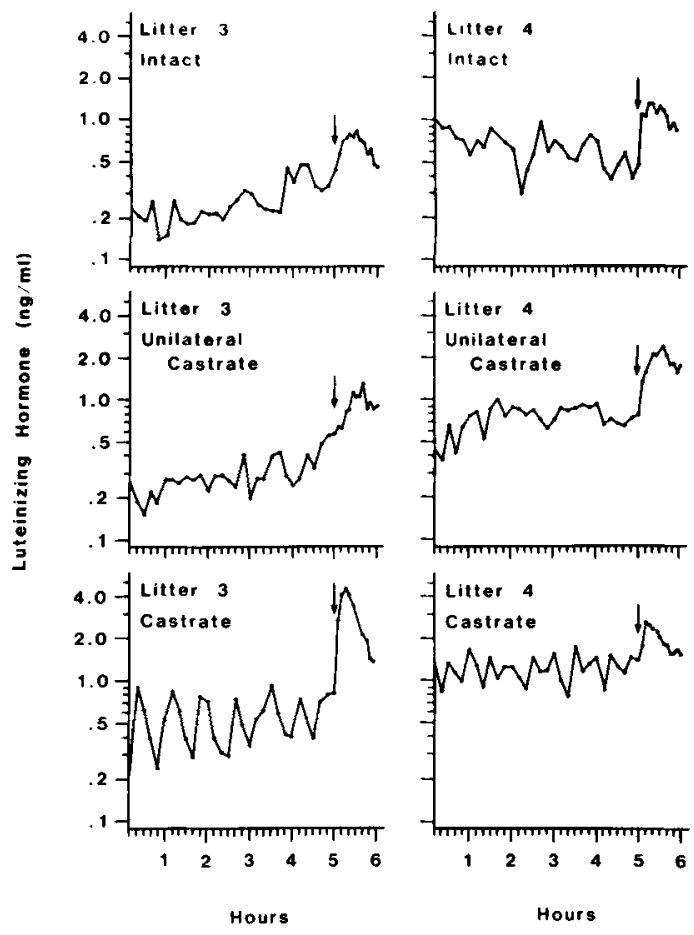

Figure 1. Plasma luteinizing hormone concentrations in individual 14-wk-old boars from the two representative litters after bilateral and unilateral castration at $10 \mathrm{wk}$ of age. Gonadotropin releasing hormone (GnRH; $40 \mu \mathrm{g}$ ) was administered at the time denoted by the arrows. repeat measurements within animals (Gill and Hafs, 1971). In each case, the data were fitted to a model that included the effects of treatment (castration), litter, treatment $x$ litter, sample, sample $x$ treatment and sample $x$ litter. The effect of treatment $x$ litter was used as the error term for testing the effects of treatment and litter. Estradiol, testosterone, testis weight, LH pulsatile release data and the measures of LH after GnRH (highest LH level, time to the highest $\mathrm{LH}$ level, magnitude of $\mathrm{LH}$ change and slope of $\mathrm{LH}$ response) were fitted to a model that included the effects of treatment and litter. Further comparisons utilized a t-test of the data that comprised the two means involved (SAS, 1979).

Average LH concentration before GnRH was calculated from $\mathrm{LH}$ determinations of all samples collected before the GnRH challenge. Estimates of $\mathrm{LH}$ at 0 min and the maximum LH after GnRH at the time that it occurred were fitted to a linear regression for each treatment group (Snedecor and Cochran, 1967).

\section{Results and Discussion}

Before the GnRH challenge, plasma LH was affected by castration $(\mathrm{P}<.001$; figures 1 and 2). Mean plasma LH in bilaterally castrated boars was higher than concentrations observed in intact boars $(982 \pm 56$ vs $389 \pm 56 \mathrm{pg} / \mathrm{ml}$;

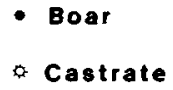

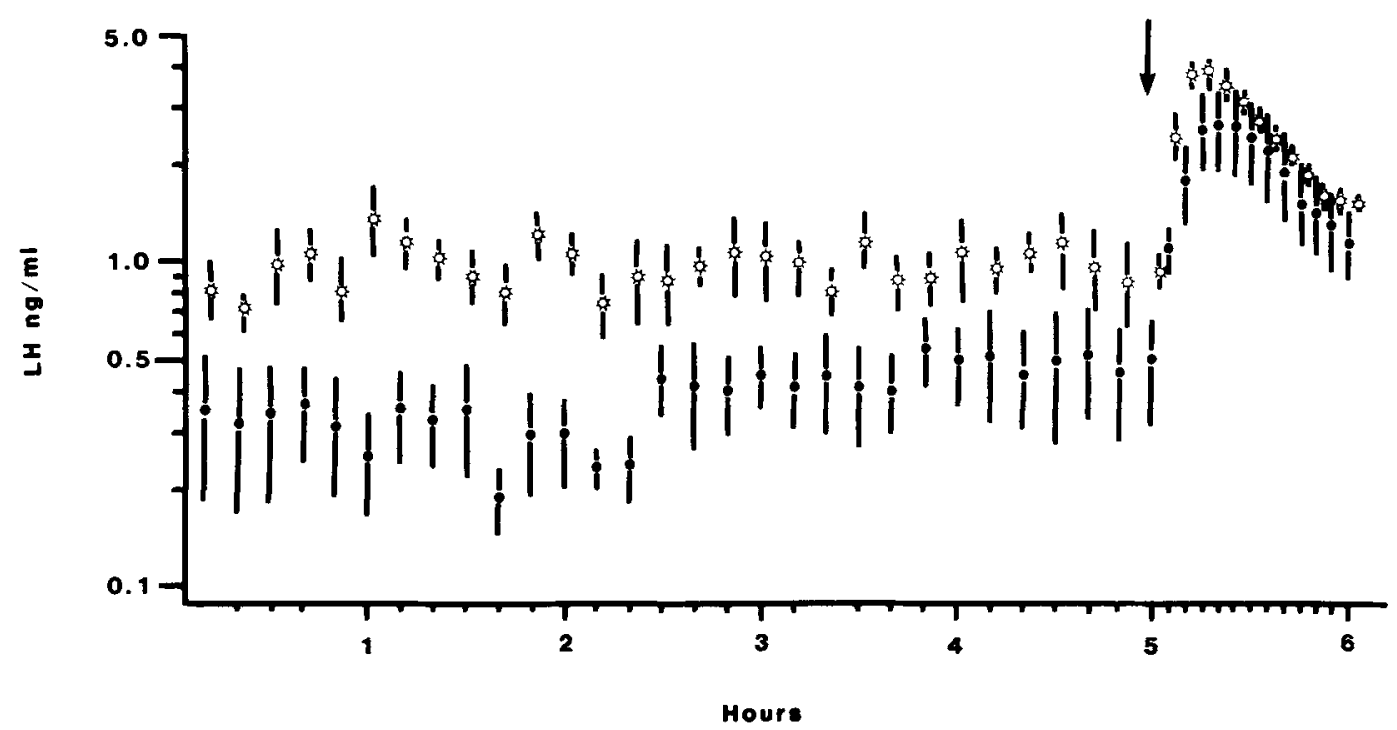

Figure 2. Mean plasma luteinizing hormone concentrations ( $\mathrm{LH} ; \pm \mathrm{SE}$ ) in intact and bilaterally castrated boars at $10 \mathrm{wk}$ of age. Gonadotropin releasing hormone ( $\mathrm{GnRH} ; 40 \mu \mathrm{g})$ was administered at the time denoted by the arrow. 
$\mathbf{P}<.001$; least-squares means $\pm \mathrm{SE}$; table 1 ). The increase of $\mathrm{LH}$ after bilateral castration confirms the observations of Colenbrander et al. (1977) and FlorCruz and Lapwood (1978) in prepubertal and adult boars, respectively. Elevated LH was also observed in long-term castrates (Pomerantz et al., 1974; Ford and Schanbacher, 1977). In the present study, bilateral castration of boars increased the number of pulsatile releases of LH during a 5 -h period $(7.0 \pm .6 \mathrm{vs}$ $2.0 \pm .6 ; \mathrm{P}<.001 ;$ table 1$)$ and the mean amplitude of the pulsatile releases of $\mathrm{LH}(617 \pm 29$ vs $360 \pm 58 \mathrm{pg} / \mathrm{ml} ; \mathrm{P}<.001$; table 1) compared with the intact boars.

The development of the LH profiles after bilateral castration is not clearly understood. Allrich et al. (1982) did not find differences in mean LH concentrations at $d 4,8$ or 16 postcastration in boars of similar age to pigs in the present experiment. However, pulsatile releases of LH were not determined in that study. It may be that as time after castration progresses, $\mathrm{LH}$ is released in a more frequent pulsatile manner. If these frequent releases are also greater in amplitude, the result would be the development of elevated mean LH concentrations.

Mean plasma $\mathrm{LH}$ in unilaterally castrated boars $(473 \pm 66 \mathrm{pg} / \mathrm{ml}$; table 1$)$ did not differ from values in intact boars. The number of $\mathrm{LH}$ pulses and the pulse height of the unilaterally castrated boars were similar to those in intact animals. Unilateral castration was included as a treatment group in an attempt to reduce concentrations of gonadal steroids in boars and to observe the effect of the reduction of gonadal steroids on LH secretion. The lack of difference between $\mathrm{LH}$ in the unilaterally castrated and intact boars may be explained by compensatory hypertrophy of the remaining testis during the 4 wk between castration and blood sample collection. Compensatory growth of the remaining testis in unilaterally castrated boars was previously observed by Sundby et al. (1981) in boars castrated at 1 to 2 mo of age and compared at 5 to 7 mo of age. Over that period of time, the remaining testis grew to within $98 \%$ of the combined size of the paired testes in intact boars and androgen concentrations at 2 to 5 mo of age were not affected by unilateral castration.

Indications that compensatory hypertrophy of the remaining testis had occurred in the present study were the absence of differences in plasma estradiol and testosterone (table 1) between the unilateral castrates and.intact boars and a larger increase in individual testis weight in the unilateral castrates than in intact boars over the period between 10 and $14 \mathrm{wk}$ of age (432 \pm 42 vs $245 \pm 34 \% ; P<.05)$.

Comparison of treatment means indicated that $\mathrm{LH}$ after GnRH (the average of 12 samples taken at 5-min intervals) in bilaterally and unilaterally castrated boars was higher than the mean concentration in intact boars $(2,588 \pm$ $147,2,693 \pm 164$ and $1,928 \pm 147 \mathrm{pg} / \mathrm{ml}$, respectively; $P<.01 ;$ table 1 ). There were no differences between intact and castrated boars in the highest LH level after GnRH and the magnitude of $\mathrm{LH}$ change after GnRH (table 1 ). The time to the highest LH level after GnRH did not differ between bilateral castrates and intact boars $(15.0 \pm 2.8$ and $21.0 \pm 2.8 \mathrm{~min}$, respectively); however, the highest $\mathrm{LH}$ was observed later in unilateral castrates $(25.5 \pm 3.3$ $\min ; \mathrm{P}<.05$ ) than in bilaterally castrated boars. The rate of $\mathrm{LH}$ response during the first $15 \mathrm{~min}$ after GnRH was not affected by castration (table 1). Comparison of the linear regression coefficient of mean pre-GnRH LH concentrations of each pig plotted at time 0 and maximum LH levels after GnRH indicated a tendency for LH in bilateral castrates to increase more rapidly than $\mathrm{LH}$ in intact boars $(b=202$ vs 94 ; $\mathbf{P}<.10$; figure 3 ). Differential responses to a uniform dose of GnRH may indicate a difference in the readily releasable pools of $\mathrm{LH}$ of castrate and intact boars. Pomerantz et al. (1974) were not able to detect differences in pituitary sensitivity to GnRH in adult intact and castrated boars. However, pigs used in that study were castrated at $4 \mathrm{wk}$ of age and sampled at 5 to 6 mo of age. The contrast between that study and the present one may be due to the possibility that long-term castrates respond differently than boars that were more recently castrated. It should be noted that Pomerantz et al. (1974) used miniature pigs as an experimental animal. These animals have different endocrine profiles during reproductive development than domestic pigs (FlorCruz and Lapwood, 1978) and comparisons may be inappropriate.

Litter affected overall mean LH concentrations $(P<.01)$ and the amplitude of pulsatile releases of $\mathrm{LH}$ before $\mathrm{GnRH}(\mathrm{P}<.001)$. If the litter effect of these variables is genetically mediated, selection on the basis of these variables may be effective. This may be a means of selecting boars for traits that influence not only their reproductive efficiency but also 


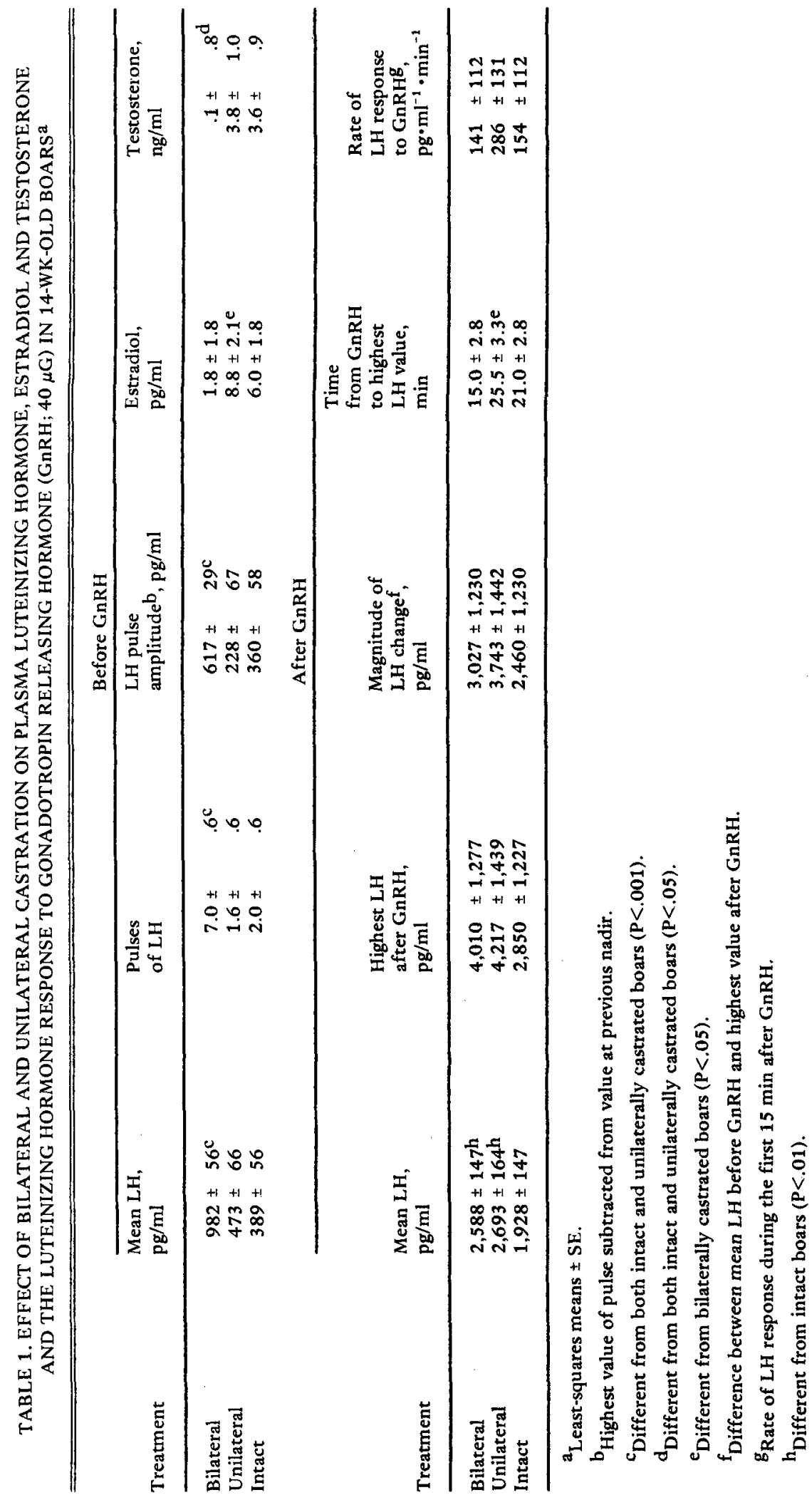




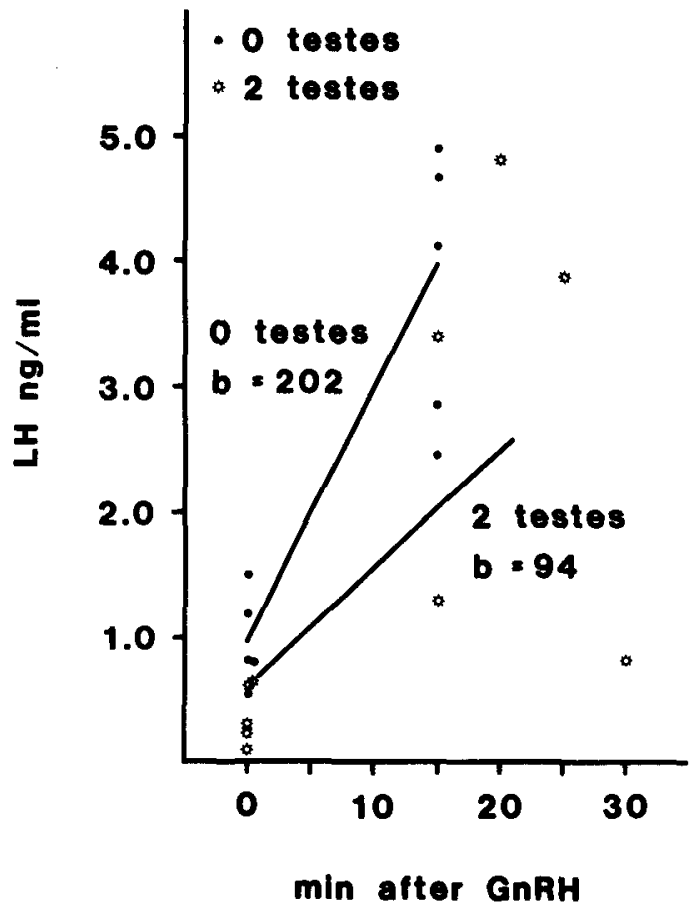

Figure 3. Plasma luteinizing hormone (LH) concentrations before and at the time of the maximum response to gonadotropin releasing hormone (GnRH; 40 $\mu \mathrm{g}$ ) in bilaterally castrated and intact boars.

the reproductive efficiency of their offspring. In the boar, differences in $\mathrm{LH}$ and gonadal steroids have been related to changes in testis size that were the result of selection (Schinckel et al., 1984). The detection of the effect of litter implies the possibility of using genetic material to create a range in certain independent variables that affect $\mathrm{LH}$ secretion. It should be noted that the effect of litter was not significant in any of the analyses of LH secretion after GnRH. This may be an indication that the balance of the hypothalamo-hypophyseal-gonadal axis was upset by exogenous $\mathrm{GnRH}$.

Data from the present study indicate that bilateral castration of boars results in an increase over intact boars in mean $\mathrm{LH}$ concentrations, number of pulsatile releases of $\mathrm{LH}$ and amplitude of the pulsatile LH releases. Presumably, these changes were the result of the removal of gonadal steroids and provide evidence that the control of LH secretion is influenced by the negative feedback of gonadal steroid hormones. The tendency of the pituitaries of bilaterally castrated boars to release more $\mathrm{LH}$ and to do so more rapidly in response to exogenous GnRH than that of intact boars suggests that changes in $\mathrm{LH}$ concentrations after castration are mediated by the absence of the negative affect of gonadal steroids on the pituitary. Also, a more frequent release of $\mathrm{GnRH}$ is indicated by the higher number of pulses of $\mathrm{LH}$ releases observed. However, the possibility that neural pathways between the gonads and the central nervous system influence gonadotropin secretion (Gerandai and Halasz, 1981) and that these pathways are severed at castration should be considered.

\section{Literature Cited}

Allrich, R. D., R. K. Christenson, J. J. Ford and D. R. Zimmerman. 1982. Pubertal development of the boar: Testosterone, estradiol-17 $\beta$, cortisol and LH concentrations before and after castration at various ages. J. Anim. Sci. 55:1139.

Colenbrander, B., Th.A.M. Kruip, S. J. Dielman and C.J.G. Wensing. 1977. Changes in serum LH concentrations during normal and abnormal sexual development in the pig. Biol. Reprod. $17: 506$.

D'Occhio, M. J., J. E. Kinder and B. D. Schanbacher. 1982a. Patterns of LH secretion in castrated bulls (steers) during intravenous infusion of androgenic and estrogenic steroids: Pituitary response to exogenous luteinizing hormone-releasing hormone. Biol. Reprod. 26:249.

D'Occhio, M. J., B. D. Schanbacher and J. E. Kinder. $1982 \mathrm{~b}$. Relationship between serum testosterone concentration and patterns of luteinizing hormone secretion in male sheep. Endocrinology 110:1547.

FlorCruz, S. V. and K. R. Lapwood. 1978. A longitudinal study of pubertal development in boars. Int. J. Androl. 1:317.

Ford, J. J. and B. D. Schanbacher. 1977. Luteinizing hormone secretion and female lordosis behavior in male pigs. Endocrinology 100:1033.

Gerandai, I. and B. Halasz. 1981. Participation of a pure neuronal mechanism in the control of gonadal functions. Andrologia 13:275.

Gill, J. L. and H. D. Hafs. 1971. Analysis of repeated measurements of animals. J. Anim. Sci. 33:331.

Kesler, D. J., H. A. Garverick, R. S. Youngquist, R. G. Elmore and C. J. Bierschwal. 1977. Effects of days postpartum and endogenous reproductive hormones on GnRH-induced LH release in dairy cows. J. Anim. Sci. $45: 797$.

Kiser, T. E., R. A. Milvae, H. D. Hafs, W. D. Oxender and T. M. Louis. 1978. Comparison of testosterone and androstenedione secretion in bulls given prostaglandin $F_{2} \alpha$ or luteinizing hormone. J. Anim. Sci. 46:436.

Niswender, G. D., L. E. Reichert, Jr. and D. R. Zimmerman. 1970. Radioimmunoassay of serum levels of $\mathrm{LH}$ throughout the estrous cycle of pigs. Endocrinology 87:576.

Pomerantz, D. K., F. Ellendorff, F. Elsaesser, A. Konig and D. Smidt. 1974. Plasma LH changes in intact adult, castrated adult and pubertal male pigs following various doses of synthetic luteinizing hormone-releasing hormone (LH-RH). Endo- 
crinology $94: 330$.

Riggs, B. L. and P. V. Malven. 1974. Spontaneous patterns of LH release in castrate male sheep and the effects of exogenous estradiol. J. Anim. Sci. 38:1239.

SAS. 1979. SAS User's Guide. Statistical Analysis System Institute, Inc., Cary NC.

Schanbacher, B. D. 1981. Importance of the episodic nature of luteinizing hormone secretion in the castrate male bovine: Interference with oestradiol17ß. J. Endocrinol. 88:393.

Schanbacher, B. D., M. I. D'Occhio and T. W. Getty. 1983. Pulsatile luteinizing hormone secretion in the castrate male bovine: Effects of testosterone or estradiol replacement therapy. J. Anim. Sci. $56: 132$.

Schinckel, A. P., R. K. Johnson and R. J. Kittok. 1984. Testicular development and endocrine characteristics of boars selected for either high or low testis size. J. Anim. Sci. 58:675.

Snedecor, G. W. and W. C. Cochran. 1967. Statistical Methods. The Iowa State Univ. Press, Ames.

Sundby, A., O. Andresen and N. Standal. 1981. Effect of hemicastration on the level of testicular steroids and growth in bulls and boars. Theriogenology 16:249. 